\title{
Incorporating Self and Peer Assessment in Reflective Teaching Practices
}

\author{
Ni Made Ratminingsih \\ Dr., Ganesha University of Education, Indonesia, made.ratminingsih@undiksha.ac.id \\ Luh Putu Artini \\ Dr., Ganesha University of Education, Indonesia, putu.artini@ undiksha.ac.id \\ Ni Nyoman Padmadewi \\ Prof., Ganesha University of Education, Indonesia, nym.padmadewi@undiksha.ac.id
}

More currently literature reviews suggests the use of authentic assessment, which aims to involve students to be more responsible with their learning. This article reports the findings of a descriptive study on student teachers' perception on the use of self and peer assessment to give evaluation on planning the lesson and teaching performance in Reflective Teaching Class. There were 100 samples taken randomly from 234 students in a survey using questionnaire and 15 students participating in the focus group discussion (FGD). The finding from the questionnaire shows that they had a very positive perception toward the use of self and peer assessment. Additionally, from the FGD, they conveyed by practicing doing self assessment, they could learn to see self performance deeply, strengths and weaknesses. From peer-assessment, they could learn collaboratively from feedback given by peers how to make a better lesson plan and perform a more effective teaching. Hence, self and peer assessment is considered beneficial for preparing the real teaching practicum and future career development. However, there are some problems challenged them, such as feeling subjectivity in assessing both self or peers, embarrassed and less confidence, and time constraints to make evaluation and reflection in the classroom.

Keywords: lesson plan, perception, reflective teaching, self and peer assessment, teaching performance

\section{INTRODUCTION}

Assessment is one of the most important aspects in education which should be dealt with by teachers during and after the process of teaching and learning. It plays a significant role to show the extent to which the students reach the learning objectives. The more valid and reliable it is, the better it contributes to the accomplishment of an instruction. It becomes an important tool to support the success of learning and provide meaningful

Citation: Ratminingsih, N. M., Artini, L. P., \& Padmadewi, N. N. (2017). Incorporating Self and Peer Assessment in Reflective Teaching Practices. International Journal of Instruction, 10(4), 165-184. https://doi.org/10.12973/iji.2017.10410a 
feedback to students (Alias et al., 2015). In a traditional style, teachers usually take control of classroom and act as authoritative figures (Orawiwatnakul \& Wichadee, 2017), who determine, judge, and give the scores of students' learning achievement or competence. In Indonesian context, based on the daily practices, teachers still employee conventional assessment which is more on the teachers' responsibility to give grades to the students' performance. Thus, the students should only accept whatever the teachers' judgement and they seldom reflect to the result of judgement. This is because they never get involved in assessing themselves and further make a reflection from the result obtained.

However, in a more current teaching practice, students should be involved in assessing their own attainment or progress in learning. Activating them to learn to assess themselves is a part of the process of overall learning, in which they can learn to be more responsible with their own learning, they can judge in which part they are still lacking and in which part they are progressing. This concern is promoted by the Indonesian government in the most current curriculum, Curriculum 2013 that teachers have to give more opportunities to the students to get involved in assessing themselves. As stated by Karami \& Rezaei (2015), it is not only the teacher to do assessment of learning, but also the students to use assessment for learning. Thus, they can learn to reflect on their own learning and to achieve the target they want.

A meaningful assessment is an assessment which provides authentic and contextual tasks. This means that they should be given the real tasks which are useful for their future career as teachers (Johnson \& Johnson, 2002). In self assessment, students make judgment about their own work, while in peer assessment they make judgment about other students' work. Both of them are student-based assessments aiming to enhance the authenticity of assessment (Alias et al., 2015). The benefits of using self and peer assessment are speed, direct involvement, encouragement of autonomy, and increase motivation as they involve themselves in the learning process (Brown, 2001). The active participation in assessment design, choices, criteria and making judgments is a more sustainable preparation for subsequent working life, in this case their career as teachers (Boud \& Falchikov, 2006).

In doing reflection in a reflective teaching practice, the student teachers are trained to assess themselves using self assessment by self-checklist and filling out self reflective journal, and peer assessment by peer-checklist in making lesson plan and in teaching performance. These student-based assessments, called as alternative assessments, which distinguish them from traditional formal assessments (Brown, 2001; Shepard, 2000). They are kinds of authentic assessment which aim to enable students to show their real ability to perform a competence. In this case, the student teachers have to be able to assess themselves, whether it is individually or with partners. By doing so, they are able to perceive their real stage of development, in which part they have strengths and weaknesses (Karami \& Rezaei, 2015). Thus, conducting reflection about the teaching practice is the most important duty for the teachers as well as those student teachers. This duty becomes not only very crucial for them in order to continuously and regularly make improvement in their teaching, but also for their students, since the teachers' 
improvement can affect the students' learning. Considering this, the student teachers should be trained to perform continuous reflection of their teaching practices in order to make them accustomed to having this activity beforehand, so when they are becoming professional teachers they can do reflection regularly as their routine professional development.

This research, then, aims to answer the following questions.

1) How is the student teachers' perception on the use of self and peer assessment implemented in reflective teaching practices?

2) What are the benefits obtained and the problems encountered by student teachers in using self and peer assessment in reflective teaching practices?

\section{CONTEXT AND REVIEW OF LITERATURE}

\section{Self and Peer Assessment}

Delivering assessment is one of the main activities that every teacher is commonly done in order to provide feedback on the students' learning. According to Walvoord (2010), assessment is a systematic collection of information to give decisions on their achievement. Knowing their attainment usually motivates the students to make a better endeavour to achieve more. The students' engagement in the learning process can make assessment more effective to affect the students' motivation and encourage their learning efficiency (Khonbi \& Sadeghi, 2012) Therefore, assessment is an important tool that must be conducted in the learning process to evaluate the targeted learning objectives in order to increase both the students' achievement and motivation.

Recently, educators in the world are putting more emphasis on the use of authentic assessment. It is regarded as a more valid tool in assessing students' real competence. Authentic assessment is any type of assessment, which is implemented in order to indicate skills and competencies, representing problems and situations likely to be encountered in daily life (Collins, 2013). It is performance-based and requires students to exhibit the extent of their learning through a demonstration of mastery. The learning process is moved beyond memorization of fact or theory, but it encourages the students to respond by using the knowledge they have learned. The characteristics of authentic assessment are namely performing a task, real life, construction/application, students' structure, and direct evidence (Mueller, 2006). Therefore, authentic assessment is a form of assessment which makes the students to perform the tasks they encounter in their daily life by using the knowledge and skills they obtain during the learning process (Marhaeni \& Artini, 2015).

Self assessment is one type of authentic assessment process of formative assessment during which the students reflect on and evaluate the quality of their work and their learning, judge the degree to which they reflect the explicitly stated goals or criteria, identify strengths and weaknesses in their work, and revise accordingly (Andrade \& Du, 2007). There are two main activities in student self assessment: (1) monitor and evaluate the quality of their thinking and behaviour when learning and (2) identify strategies that improve their understanding and skills. Hence, self assessment occurs when the students 
judge their own work to improve performance as they identify discrepancies between current and desired performance (McMillan \& Hearn, 2008). It is a strategy of self reflection on the mistakes and weaknesses that the language learners conduct in using the language (linguistic), organization of discourse, and style of language use (non linguistic), which they should improve in the process of their learning. It is a metacognitive element which has an important role in the process of learning. Through self assessment, the students are able to decide what they know and what they do not (Marhaeni \& Artini, 2015), thus they can identify what needs further work (McMillan \& Hearn, 2008). It encourages them to set higher goal and commit more personal resources or effort to them (Rolheiser \& Ross, 2005). Furthermore, Kayler \& Weller (2007), and Mok et al. (2006) state that the self-assessment can improve the students' ability of selfjudgment through analysis of their own works and enable to develop their skills of critical awareness. They also emphasize that correctly implemented self assessment can promote intrinsic motivation and empower them to guide their own learning and internalize the criteria for judging success. Thus, self assessment is obviously beneficial to increase students' awareness of their learning, to enable them to analyse and judge their mastery and progress and further to recognize what they should do to improve.

Peer assessment alternatively is an assessment conducted by a student to measure other student's work. Peer assessment is defined as a kind of measurement which requires students to provide either feedback or grades (or both) to their peers on a product or a performance, based on the criteria of excellence for that product or event which students may have been involved in determining (Boud \& Falchikov, 2006). Through peer assessment, peers can provide constructive feedback to one another in order to make judgment and also allows them to compare their works with each other (Liu \& Carless, 2006; Bloxham \& Boyd, 2007). This kind of assessment can build a positive learning environment which makes the students learn in a collaborative activity. Working in cooperation can encourage the students to be more interactive to share what they understand or do not yet understand, what they obtain what they do not. This peer interaction can encourage them to learn from one another to get higher grade or improve achievement (Kollar \& Fischer, 2010). It can increase enthusiasm in learning, so that they are able to develop academically, cognitively and emotionally (Vickerman, 2009). Hence, it enables them to have a good quality of the performance or product (Cheng \& Warren, 2005). For this regard, it is proven to be an effective approach for classroom evaluation (Shepard, 2000). Spiller (2012) further describes some advantages of using peer-assessment, such as (1) it can encourage collaborative learning through interchange about what constitutes good work, (2) students can help each other to make sense of the gaps in their learning and understanding and to get a more sophisticated grasp of the learning process, (3) engaging in commentary on the work of others can heighten their own capacity for judgment and making intellectual choices, (4) receiving feedback from their peers can get a wider range of ideas about their work to promote development and improvement, and (5) peer evaluation helps to lessen the power imbalance between teachers and students and can enhance the students to be more responsible in the learning process. 
Based on all of the above points of views, self and peer assessment is not merely as an evaluation strategy, in which the students assess their strengths and weaknesses, but more importantly as a teaching and learning strategy that brings benefits to students to enable them to monitor what they learn, to make adjustment, to change their thinking, and to improve themselves in order to reach the targeted objectives. As well, it is also beneficial to the teachers to gather information on their students' needs and problems of the material that they have learnt.

\section{Previous Studies on the Use of Self and Peer Assessment}

Several studies have proven the role of self and peer assessment. Munoz \& Alvarez (2007) surveyed 94 college students in Colombia and justified that they had positive attitudes toward self assessment. Ross (2006) proved that properly implemented self assessment was able to enhance students' motivation, confidence, and achievement. Panadero et al. (2012) found that self assessment had an effect on self regulated learning and self efficacy. Honsa (2013) also found that self assessment had an effect on learner autonomy. Additionally, a study by Sharma et al. (2016) uncovered two findings, the strength and the limitation. The strength of using self-assessment was able to improve students' interest and motivation level for the subject which affects better academic performance, while the limitation was in terms of time consumption. It was reported that teachers needed more time allotment in conducting self-assessment for the students.

On the other hands, the study on the use of peer assessment gave a significant result in learning process. White (2009) investigated the use of peer assessment using a survey to a group of 55 students taking Public Speaking in EFL context in Japan, the result shows that they had a positive perspective which led to the promotion of student learning. Azarnoosh (2013) proved that peer involvement created opportunities for interaction and increased objectivity in assessment. In addition, focusing on peers' strengths and weaknesses could not only enhance students' learning, raised their level of critical thinking, and led them to autonomy. Furthermore, Sun et al. (2015) in an experimental research verified that peer assessment had an effect towards the students' achievement.

Combining both self and peer assessment, Nortcliffe (2012) in her five year study found out that self and peer assessment is an effective means to provide suitable and detailed feedback to others and timely opportunities to reflect upon the students' learning and understanding. The students also agreed that self and peer assessment is a fair method to assess individual contribution to group work. Li \& Chen (2016) in a case study discovered that peer and self-assessment could explicitly and effectively pursue deep learning, working with others, moving beyond dependence and independence to interdependence. Furthermore, Siow (2015) uncovered that self and peer assessment could enhance students' critical thinking, make them more developed and worked in a more structured way, which therefore improved their learning ability. Similarly, Willey \& Gardner (2009) justified that the use of self and peer assessment made a significant contribution to students' learning outcome, and Harris \& Brown (2013) in a case study identified that these two kinds of student-led assessment practices had the potential to positively affect achievement. 
All the findings above indicate that self and peer assessment encourages the students to learn in a meaningful way by doing reflection and giving feedback. Thus, self and peer assessment is a powerful tool to make the students not only more motivated to study, but also be more autonomous, self directed and be able to use their higher order thinking to set on their own goal of what to learn and how to learn, judge on their level of achievement, and further knows what to do to make improvement.

The studies conducted by Munoz \& Alvarez (2007), Ross (2006), Panadero et al. (2012), Honsa (2013), White (2009), Sun et al. (2015), and Willey \& Gardner (2009) were mostly quantitative research focusing on the effect of self-peer assessment on students' achievement such as certain variable such as students' achievement or learning outcome, attitude, motivation, confident, self-regulation and self-efficacy, while studies conducted by Sharma et al. (2016), Azarnoosh (2013), Nortcliffe (2012), Li \& Chen (2016), Siow (2015), and Harris \& Brown (2013) were mostly qualitative study such as case study tried to reveal the strength and weakness of self-peer assessment applied to the students descriptively. However, there are no studies the current researcher yet found on the use of self and peer assessment in doing reflective teaching practices. Basically, this study is focusing on revealing the student teachers' perception in employing selfpeer assessment on reflective teaching course. More importantly, the reflective teaching is the most current course appears in the academic year 2015/2016 in the latest curriculum of English Education Department in Ganesha University of Education, where this research was conducted. Thus, this research is fruitful to be held.

\section{Reflective Teaching}

To be effective teachers in this Information Age is a great challenge. They need not only to understand their students' background and learning preferences, but also to take positive action to improve the educational outcomes for their students. In order to do so, they should perform regular, authentic reflection (Sellars, 2012). Reflective teaching is defined as a systematic self evaluation cycle conducted by teachers toward their own teaching through an open discussion with colleagues or written analysis. Since it is a cyclical process, the teachers should monitor, reflect, evaluate and revise their own practice continuously in order to meet the high standard of teaching (Jacobs et al., 2011). It is an approach in which the teachers verify their own action and attitudes, then consider the way to improve them as the guidance for future actions (Conley et al., 2010). It is conducted based on day-to-day experiences and take them as benefits for the planning process (Borich, 2000). Combining theoretical framework from several experts, there are four characteristics of reflective thinking practices. Those are reflection as retrospective analysis, reflection as problem solving, critical reflection of self, and reflection on beliefs about self and self-efficacy. Reflection as retrospective analysis deals with self assessment, reflection as problem solving refers to awareness of what to learn after the assessment, critical reflection of self concerns with developing continuous improvement, and reflection on beliefs and self-efficacy cope with feelings and awareness of having ability to attain goals (Choy \& Oo, 2012). Learners who think reflectively become aware of and control their learning by actively accessing what they know, what they need to know and how they bridge that gap (Sezer, 2008). 
Reflective teaching aims at improving their achievement to accomplish the standard of teaching itself or improve professional practice (Gay \& Kirk, 2003; Schuck et al., 2008; Zwozdiak-Myers, 2011; Sellars, 2012) and to develop further self knowledge and understanding (Sellars, 2012), which has an impact on the students' learning potency to improve their learning achievement (Zwozdiak-Myers, 2011). Therefore, it is a continuous and ever lasting cyclical process in someone's profession as a teacher (Zhu, 2014). Reflection can help teachers to respect their roles as the builders of knowledge and education (Killen, 2007). Through conducting a thorough reflection toward the teaching experience they have done, they can develop deep comprehension to help themselves and others to alter their teaching process to be better. This indicates that reflective teaching focuses on collaborative activities among colleagues in which they should complete one another to improve their teaching. Thus, it is it is a crucial 'lifelong professional development', which is applicable in all educational situations, including teaching the language (Wallace, 1998). The process of reflection can be enhanced when it is provided with video recording as the basis of analysis (Orlova, 2009). Therefore, prospective teachers need to be empowered to become reflective professionals who reflect continuously on experience and devise new patterns of action aimed at improving student learning and achievement. In order to achieve it, the teaching practicum should provide prospective teachers with insights into the principles and practical tools of reflective teaching. The most prominently is that the prospective teachers should be encouraged to devise their own professional development plans to be pursued in their actual teaching practice (Insuasty \& Castillo, 2012).

From all of the aforementioned literature reviews, it is obvious that reflective teaching is very essential to be practiced by student teachers in particular and teachers in general in order to continuously improve the quality of their teaching by working collaboratively with others. Moreover, reflective teaching is notably the most current course inserted in the latest curriculum of English Education Department of Universitas Pendidikan Ganesha, Bali. Therefore, student teachers should be involved to give evaluation towards the implementation of the course in terms of their perception, benefits, and problems faced along the application of self and peer assessment.

\section{METHOD}

\section{Research Design}

This research is a descriptive research using a survey method to answer the first research question. Furthermore, FGD is used to answer the second research question. From this design, the researcher tried to describe as it is how the students perceived the use of self and peer assessment, whether or not they liked and understood the use of it, what benefits they obtained, and problems encountered.

\section{Population and Sample}

The population of this research was the sixth semester students of English Education Department in academic year 2015/2016 with the total number 234. The samples of the study consisted of 100 students. The determination of samples taking consideration from 
Cohen's theory, it has reached forty three percentage of the population which was categorized as medium size.

Table 1

Description of the total Samples

\begin{tabular}{llll}
\hline No & Class & Number & Sample \\
\hline 1 & Class 6A & 33 students & 14 students \\
\hline 2 & Class 6B & 32 students & 13 students \\
\hline 3 & Class 6C & 28 students & 12 students \\
\hline 4 & Class 6D & 28 students & 12 students \\
\hline 5 & Class 6E & 31 students & 13 students \\
\hline 6 & Class 6F & 24 students & 11 students \\
\hline 7 & Class 6G & 30 students & 13 students \\
\hline 8 & Class 6H & 28 students & 12 students \\
\hline
\end{tabular}

From 100 samples, there were 15 participants chosen from different classes to be the participants of FGD.

\section{Instruments}

The instruments used were questionnaire and a list of questions delivered in FGD. The questionnaire was used to collect data on the students' perception on the use of self and peer assessment. There were 10 valid items used in the questionnaire using Likert Scale (1-5 intervals) grounded from the theory of perception proposed by Wenden (1991) and Jain (2014) which classifies perception into three components, namely cognitive (agreement and understanding), affective (like and dislike), and behavioural (implementation).

The questionnaire was tested primarily to measure the content validity by using two expert judgments giving their agreement and disagreement on the questionnaire items. The results of the judgment were calculated using Gregory formula. For empirical validity, the questionnaire was tried out and measured their validity and reliability. The validity of the test was computed using Product-moment Correlation. Furthermore, the reliability of the questionnaire was analyzed by using Cronbach Alpha.

The content validity of the questionnaire covering 15 items was 1.00 which indicates that the questionnaire had very high content validity. Empirically, the validity which was calculated by Product-moment Correlation involving 33 students with the significance value (0.05) had $\mathrm{r}_{\text {table }}=0.35$. There were 4 items dropped and 11 items were valid. The valid items were then computed their reliability, and the result was 0.82 . It signifies that the questionnaire attained very high reliability.

FGD was conducted by employing six questions. They were used to have some further responses from the participants on the benefits they obtained and the problems they faced when they studied reflective teaching by utilizing self and peer assessment. 


\section{Data Collection}

Data were collected through some procedures namely; (1) the questionnaire was distributed to all samples at the same time spending around 20 minutes, and (2) FGD involved 15 participants was conducted about one and a half hour after the questionnaire distribution, which was video taped in order to have accurate data for analysis. All of participants were seated in U-shape seating arrangement and the researcher proposed each question from the list and then all of them could freely answer as what they wanted to say. They voluntarily responded to any question delivered.

\section{Data Analysis}

The collected data were then analysed descriptively, using quantitative and qualitative interpretation. Data from the questionnaire deployed numerical calculation of the percentage, while data from FGD were presented qualitatively, based on the nature of the participants' responses.

The formula used to calculate the percentage of the data gathered from questionnaire is follows:

\section{Percentage $=$ Total Score obtained $\times 100 \%=$ Maximum Score}

In order to classify the students' level of perception on the use of self and peer assessment in reflective teaching practices, below is the criteria of perception used.

Table 2

Criteria of Perception

\begin{tabular}{ll}
\hline Percentage & Criteria \\
\hline $\mathrm{Pc} \geq 85 \%$ & Very positive \\
\hline $70 \leq \mathrm{Pc} \leq 84$ & Positive \\
\hline $55 \leq \mathrm{Pc} \leq 69$ & Moderate \\
\hline $40 \leq \mathrm{Pc} \leq 54$ & Negative \\
\hline $\mathrm{Pc} \leq 39$ & Very negative \\
\hline
\end{tabular}

\section{FINDINGS}

The result of the questionnaire is presented in the following table.

Table 3

Gained Score and Percentages

\begin{tabular}{lcc}
\hline Dimension & Gained Score & Percentage \\
\hline Agree to the use of self and peer assessment & 489 & $97.8 \%$ \\
\hline Like the use of self and peer assessment & 483 & $96.6 \%$ \\
\hline Understand the nature of self and peer assessment & 464.5 & $92.9 \%$ \\
\hline Able to utilize self and peer assessment & 473.3 & $94.7 \%$ \\
\hline $\begin{array}{l}\text { Able to improve competence in designing lesson plan } \\
\text { and performing teaching }\end{array}$ & 477 & $95.4 \%$ \\
\hline
\end{tabular}

Table 3 above shows that the percentages of the gained scores are all above 85 . They highly agreed and liked the use of self and peer assessment. 


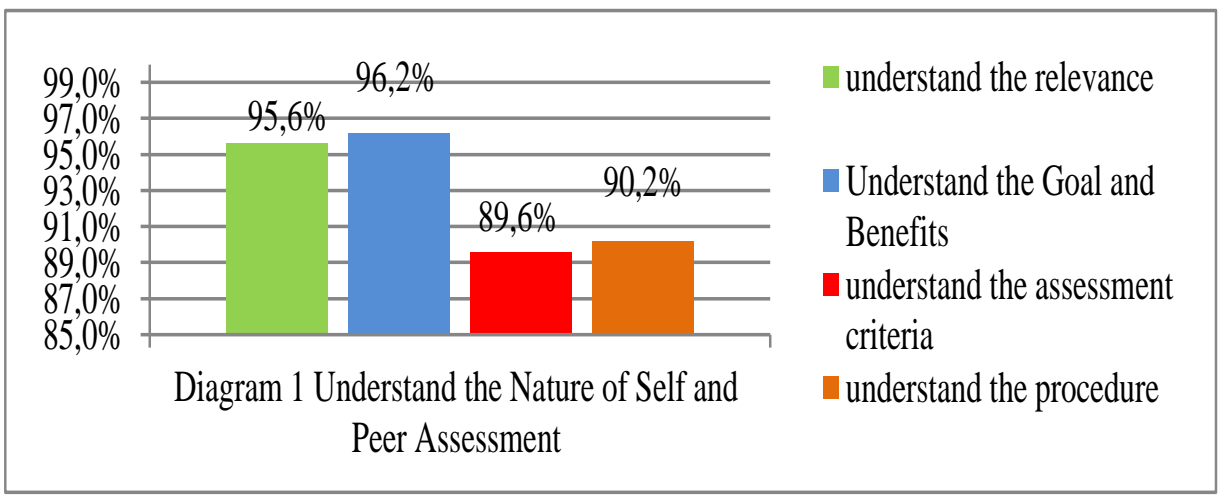

Diagram 1 proves that the students had a very good understanding on the goal and benefits of using self and peer assessment (96.2\%). They also understood well the relevance of those assessments in reflective teaching course in order to train them to reflect on themselves either individually or through peers $(95.6 \%)$. Furthermore, they also understood clearly the procedure on how to apply the assessment and the criteria used to assess. Among the four, however, the percentage of understanding the criteria is the lowest. This signifies that they need to be given more grounding in terms of using certain assessment criteria. Diagram 2 below shows the student teachers' perception on their ability to use self and peer assessment.

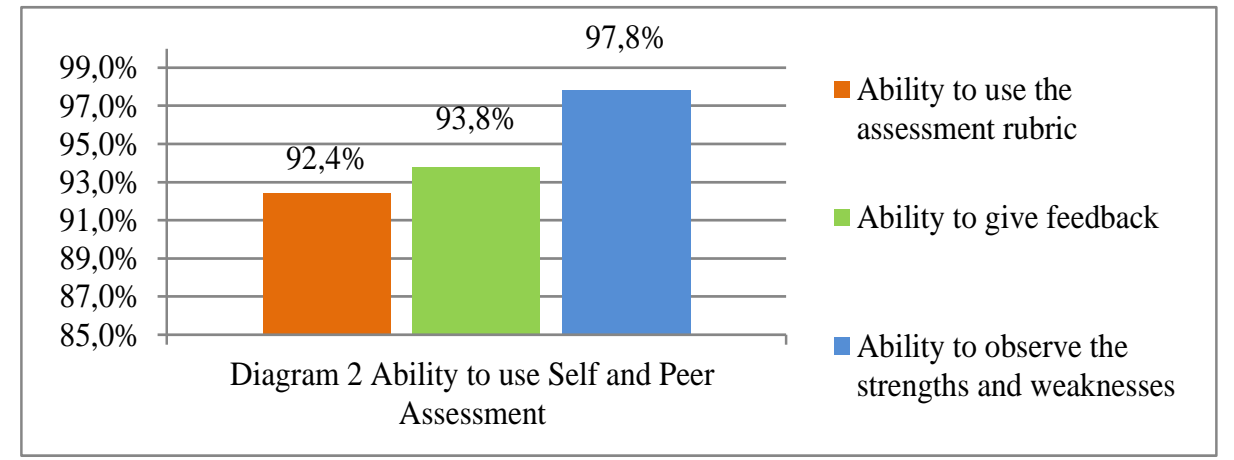

It can be seen from diagram 2 that the student teachers had a very positive perception on their ability to utilize self and peer assessment. They perceived themselves $(97.8 \%)$ of having ability to observe strengths and weaknesses, followed by having their ability to give feedback, and also to use the rubrics. These abilities, thus, drove them to perceive that self and peer assessment could improve their competence in designing the lesson plan and performing teaching (see table 03 above).

By calculating the total score obtained (4727) divided by the maximum score (5000) of 10 items of questionnaire with the use of Likert Scale (1-5 interval) and the total number of respondents (100 students), the percentage obtained is $94.54 \%$. This demonstrated that they had a very positive perception on the use of self and peer assessment. 
From FGD, the students' perception on the use of self and peer assessment is intensified. The translated question and their responses are presented below.

Table 4

The Result of FGD

No. Question by Students' answer

the

researcher

1 Do you Student 1 : Yes, I do agree. As we know, reflective teaching is a course that guides agree with prospective teachers to make reflection or evaluation on the performance of their teaching, the use of so that they can improve the skill or technique in teaching. Peer assessment done by peer is self and peer able to give evaluation when the practicing teacher does not realize their weakness, while assessment? self assessment makes him/her to reflect on himself or herself. Peer and self assessment result can be compared to see whether they are in agreement. Student 2:

Yes, I agree why self assessment or peer assessment is used in reflective teaching. This is because I realize that the teacher should reflect on self. They become more sensitive and know exactly what is going on in the class room. The help from peer assessment is to evaluate and give inputs of the weaknesses of the performance in the class room. Student 3:

In my opinion, self assessment is assessment that should come from the teacher, but peer assessment comes from outside of the teacher. For example: self assessment shows the teacher's feeling of what is experienced in the classroom which motivates them to make a change, while from peer assessment, they are going to be helped by their friends in terms of their performance and how they teach in the class.

Student 4:

Well, I will add a bit. Yes, I agree with self assessment and peer assessment. First, from self assessment, we are able to reflect on ourselves of what we did and why we did so, and what the weaknesses are. From the weaknesses, we should make revisions, from strengths we can increase more. Next, in peer assessment, we can get different perspectives from what we did. Thus, it is not enough by only looking at self, but also others.

2 Which one Student 4:

should be In my opinion, both should be balanced. Usually, people will give more emphasis on more paid weakness, but forget their strengths. Strengths can be a motivator to perform better, while attention to? weaknesses can be a stepping stone to become better. So both strength and weakness Strength or should be equally paid attention to.

weakness? Student 1:

In my opinion, when we see strength we can be more confident so that we can even improve to be better. When we see weakness, we know in which part we are still lacking to make improvement, so that gradually it can become strength. If I should choose which one is more important, I will say that weakness is more important. Why? Because weakness should be evaluated and reflected to change it into strength. Very often we do not realize our weaknesses, we even seldom evaluate them. So, weaknesses should be more focused on.

3 Why do you Student 5:

consider Because by conducting reflective teaching, we are able to realize ourselves in doing that self and teaching in the class.

peer From self assessment, we can realize what we have done in the class both strengths and assessment weaknesses. On the other hands, as stated by student 4 , we also need to know others' are relevant perspective on what we have done. Thus, both self and peer assessments are relevant to to reflective conduct reflective teaching. Thanks.

teaching? Student 6:

In my opinion, self and peer assessment is very relevant in reflective teaching. This is because there are rubrics available which are suitable for evaluating teaching performance and lesson plan. For example in $N 1$ rubric, we can learn how to design a lesson plan and N2

International Journal of Instruction, October $2017 \bullet$ Vol.10, No.4 
rubric we can see how good we are in teaching in the class, and from self assessment rubric we can tell what we have done, problems that we face and how we can revise those mistakes. So we can avoid doing the same things next time. Thus, those rubrics can be concluded to be very relevant in reflective teaching activity.

4 Do you like Student 7:

the use of Well, thank you for the time. I will answer the question. In my opinion, I like them, because self and peer as teachers, we should know our weaknesses, strengths, and how we manage the situation assessment? in the class. Definitely, we can say all of them can be done by using self and peer assessment. If a teacher can do so, he/she will be happy knowing what he/she should improve when they realize having weaknesses. Direct comments from peers are important. Thus, if there are weaknesses done by the teacher, they can be revised, and from the strengths the teacher must also continuously improve to be better again.

Student 8:

I don't really like it. Because the rubric is too detailed, so that I am a little bit stress in the process. The lesson which I get from the use of rubric is that it is difficult as it is too detailed. So I experience difficulties especially in the first time using it. But at the end, I understand about it and I'm glad I did it. Because it is the fact as a prospective teacher I must understand about it, which I have never obtained before in the previous courses.

Student 9:

I like self assessment because I can express about things that go wrong in the way I have taught and the problems that I faced when I was teaching. From peer assessment, I can know my weaknesses and my strengths from the feedback given by peer assessment.

5 What Student 4:

benefits do I want to add that the use of self and peer assessment is to develop the quality as a you get from professional teacher later on. As professional teachers, we should go through the process to self and peer become better. We realize that knowledge is developing, so we should catch up and assessment? develop our teaching. If not, we will be left behind. Self and peer assessment helps us to be more thoughtful.

Student 2:

I think I agree with student 4 . In this context we use self and peer assessment as prospective teachers, after taking this course, we are going to follow real teaching practicum in the school. Using self and peer assessment, we can practice correcting mistakes in designing lesson plan and in performing teaching. So, the way we assess here can be practiced in doing real teaching practicum, to help ourselves better. Student 10:

As stated by student 4 , if a teacher continuously does reflection, it is for sure he/she can develop professionalism. Indirectly, when the teacher becomes a professional teacher, he/she can help their students improve the quality of their learning.

6 What are the Student 11:

problems In my opinion, in using self and peer assessment, I am confident in assessing myself and faced? others. But, there is a bit of problem in the form of objectivity. It is difficult to be very objective.

Student 12:

I have the same opinion with student 11, especially in assessing peers, I often feel embarrassed to give low score because of being pity, so that we feel less confident in giving objective assessment.

Student 10:

In my opinion, I am confident with self assessment because as far as I know we can freely judge ourselves based on our performance, but in assessing others, we should think twice because if other peer judges another peer is not good, while the other judges differently, we may feel embarrassed then.

Student 13:

In my opinion, I am sure in using peer assessment because in assessing our peers we should learn to be objective. I feel confident to give score 3 or even lower than 3 , because from giving this objective score our peers can realize their weaknesses from their performance,

International Journal of Instruction, October $2017 \bullet$ Vol.10, No.4 


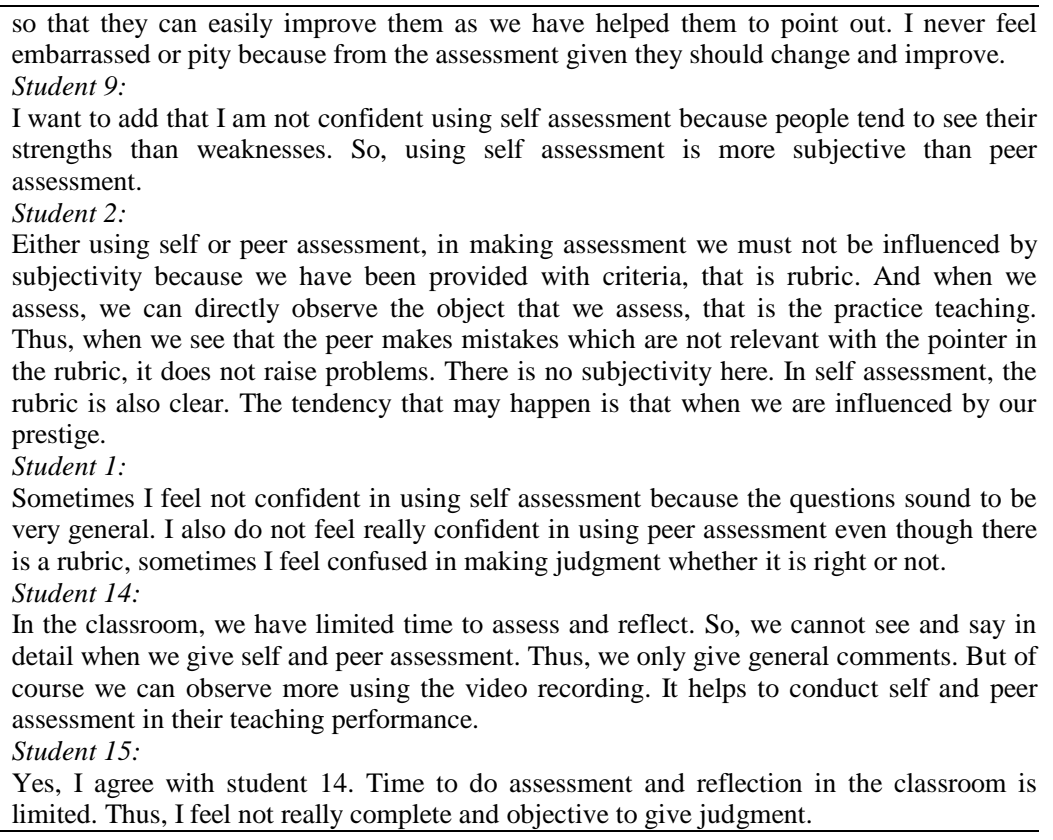

Taking a closed look at the responses given from table 4 above, it can be proven that the student teachers generally had a clear understanding on the use of self and peer assessment. They agreed upon their uses in conducting reflective teaching practices as they could see their strengths and weaknesses by doing self reflection, while from peer assessment they got different perspectives from others to find out the problems they might not see themselves. Additionally, they stated that both strengths and weaknesses should be equally paid attention to. Knowing the strengths made them more confident and encouraged to perform better, meanwhile weaknesses could be used as a whip to make progress. They also reconfirmed that self and peer assessment was relevant to conduct reflective teaching. In reflective teaching class, the student teachers should learn to reflect themselves. The provided rubrics (N1 and N2) could be used for evaluating the lesson plan and teaching performance. Using $N 1$ rubric, they could observe the prepared lesson plan, $N 2$ rubric, they could see how good their teaching performance, and from self reflective journal they could reflect what they have done, problems they faced and what to do to revise them.

Being asked whether they liked the use of self and peer assessment, they generally responded that they liked it, but an interesting finding came up from student 8 that she did not really like it in the beginning as the rubric was too detailed, which made her stressful to give assessment and feedback to their peers. But, along the process of several practices she became understand and was glad, even she realized that learning to reflect is an important duty of being a prospective teacher. On the other hands, they also raised the problems they faced when deploying self and peer assessment. Though some of the student teachers were confident in using it, several others felt it was difficult to be objective, especially when they did peer assessment. They felt embarrassed and pity and 
had to think twice to give low score to their peers, so that they felt less confident to be as objective as it was required. There was also a case that a student stated that she was not really confident in using self assessment because there was a tendency that people saw more of the strengths than weaknesses, so the assessment result could be more subjective. The other also explained that she still felt confused in making judgment whether it was right or not, which made her unconfident. Moreover, time constraint was also stated as the challenge to give assessment and feedback in the classroom, so they could not be very complete and detailed, thus they could not be very objective, too.

\section{DISCUSSION AND CONCLUSION}

Based on the findings presented above, they significantly agreed and liked the use of self and peer assessment. Their agreement and liking on it are mounted from the benefits which made them able to see the quality of their work (Andrade \& Du, 2007; Marhaeni \& Artini, 2015: Rolheiser \& Ross, 2005; Cheng \& Warren, 2005), improve ability in giving judgment (Kayler \& Weller, 2007; Mok et al., 2006; Liu \& Carless, 2006; Bloxham \& Boyd, 2007), and increase their motivation in learning (Vickerman, 2009), which further improve their lesson planning and teaching performance.

Their good understanding on what and how to use self and peer assessment provoked the student teachers to make more effort to apply them (Rolheiser \& Ross, 2005), build positive learning atmosphere among peers, which make them learn how to see strengths and weaknesses (Kollar \& Fischer, 2010), and be aware of what they mastered and did not master (McMillan \& Hearn, 2008; Nortcliffe, 2012; Marhaeni \& Artini, 2015). This result emphasises Ross (2006), Willey \& Gardner (2009), Azarnoosh (2013), Sharma et al. (2016), and $\mathrm{Li} \&$ Chen (2016) that the accurate implementation of self and peer assessment is able to enhance students' enthusiasm, motivation and confidence to learn. Additionally, it can affect on a more autonomous learning (Honsa, 2013; Azarnoosh, 2013; Panadero et al., 2012). Hence, it is able to improve achievement or learning outcomes (Ross, 2006; Willey \& Gardner, 2009; Harris \& Brown, 2013; Sun et al., 2015; Siow 2015).

Considering the student teachers claimed in the beginning of practice, it was difficult to conduct self and peer assessment that instigated stress, confusion, and uncertainty whether or not they did it right, they should then be given regular and continuous practices which make them accustomed to implementing it. Along the process of learning within one semester, they finally convinced that they became understand and realized its importance of conducting reflective teaching practices as prospective teachers for their professional development. This approves Gay \& Kirk (2003), Schuck et al. (2008), Zwozdiak-Myers (2011), Sellars (2012), and Insuasty \& Castillo (2012) that they should be done in a regular and continuous basis to improve professional practice, particularly improving the lesson planning which is subsequently actualized in real teaching practice. In addition, regularity of practices in reflective thinking practices also reinforces critical thinking ability (Sezer, 2008; Choy \& Oo, 2012; Azarnoosh, 2013; Siow, 2015).

Furthermore, the student teachers pointed out some of benefits that they perceived from doing self and peer assessment: (1) to develop their professionalism, (2) to improve their 
teaching performance, (3) to prepare for the real teaching practicum in the school, and (4) to improve the students' quality of their learning. This is in harmony with Schuck et al. (2008), Ross (2006), Harris \& Brown (2013), Sun et al. (2015), and Siow (2015).

Among the problems they declared to be encountered are first they felt dishonoured, sympathetic, and thoughtful to give low score to their peers, so that they felt less confident to be as objective as it was required. This interesting finding is typical occurrence in eastern culture as they felt unease to judge others lower than themselves. It promotes Alias et al. (2015) that the students' reluctance to rate others lower than themselves or their belief that others are better than them are considered as the values of humbleness in eastern culture. This subjectivity in giving scores to their peers influences fairness, thus it is less reliable (Kaufman \& Schunn, 2011). Next, there was also a case that a student even stated that she was not really confident in using self assessment because there was a tendency that people saw more of the strengths than weaknesses, so the assessment result could be more subjective, which did not represent the real competence. Another problem was the tendency of confusion in making judgment whether or not it was right, which created inconfidence. According to Thomas, Martin, and Pleasants (2011), this could be solved by giving the student teachers sufficient time to prepare to discuss the rationale of using the self and peer assessment which could enhance their higher order thinking. Moreover, time constraint was also stated as the challenge to give assessment and feedback in the classroom, so they could not be very complete and detailed, thus they could not be very objective, too. This finding echoes Sharma et al. (2016) and Li \& Chen (2016) that the most obvious limitation of using self and peer assessment is the difficulty of implementing it with a large group of students, thus it spends much time. Luckily, the video recording as advocated by Orlova (2009) could help them to observe the teaching performance more thoroughly, so that they could reflect more in a written form as a report.

Considering the research question is to identify the student teachers' perception on the use of self and peer assessment, the findings from the questionnaire and FGD demonstrated that they had a very positive perception on the use of more currently promoted authentic assessment in their learning, which made them actively involved along the process. Remarkably, they felt that self and peer assessment assisted them to think critically on evaluating themselves both individually and peers in conducting reflective teaching practices, which enabled to guide them to make improvement in both lesson planning and teaching performance. This finding implies that the utilization of self and peer assessment should be optimized in order to help both student teachers and teachers to enhance their teaching performance through realizing the strengths and revising the weaknesses. Realizing that, they were still confronted by the obstacles, such as subjectivity, embarrassment and less confidence as well as time restriction. Therefore, it is recommended to give the student teachers' strong foundation of knowledge on using self and peer assessment constantly and habitual practices which make them more confident and objective to assess themselves.

This study is limited on investigating the student teachers' perception. Thus, further research can be broadened in terms of the number of participants, involving not only 
student teachers but also teachers in the form of pre-service and in-service teacher training program.

\section{REFERENCES}

Alias, M., Masek, A., \& Salleh, H. H. M. (2015). Self, peer and teacher assessments in problem based learning: Are they in agreements? Procedia - Social and Behavioral Sciences, 204, 309-317.

Azarnoosh, M. (2013). Peer assessment in an EFL context: Attitudes and friendship bias. Language Testing in Asia, 3(11), 1-10.

Andrade, H., \& Du, Y. (2007). Students responses to criteria-referenced self-assessment. Assessment and Evaluation in Higher Education, 3(22), 159-181.

Bloxham, S., \& Boyd, P. (2007). Developing effective assessment in higher education: A practical guide. Berkshire: Open University Press.

Borich, G. D. (2000). Effective teaching methods. New Jersey: Pearson Education.

Boud, D., \& Falchikov, N. (2006). Aligning assessment with long-term learning. Assessment and Evaluation in Higher Education, 31(4), 399-413.

Brown, H. D. (2001). Teaching by principles: An interactive approach to language pedagogy. New York: Addison Wesley Longman, Inc.

Cheng, W., \& Warren, M. (2005). Peer assessment of language proficiency, Language Testing, 22(3), 93-121.

Choy, S. C. \& Oo, P. S. (2012). Reflective thinking and teaching practices: A precursor for incorporating critical thinking into the classroom? International Journal of Instruction, 5(1), $167-182$.

Collins, R. (2013). Authentic Assessment: Assessment for learning, Curriculum and Leadership Journal, 11(7), Retrieved 04 April, 2017 from http://www.curriculum.edu.au/leader/authentic_assessment_assessment_for_learning,36251. html?issueID $=12745$

Conley, L., et al. (2010). Becoming a teacher. London, EN: Heinemann.

Gay, G., \& Kirkland, K. (2003). Developing cultural critical consciousness and selfreflection in preservice teacher education. Theory into Practice, 42(3), 181-18.

Harris, L. R., \& Brown, G. T. L. (2013). Opportunities and obstacles to consider when using peer- and self-assessment to improve student learning: Case studies into teachers' implementation. Teaching and Teacher Education, 36, 101-111.

Honsa, S. (2013). Self-assessment in EFL writing: A study of intermediate EFL students at a Thai University. Voices in Asia Journal, 1(1). Retrieved 15 March, 2017 from www.teachingenglish.org.uk/.../self-assessment-writing-a-study-intermed

Jacobs, M., Vakalisa, N. C. G. \& Gawe, N. (2011). Teaching-learning dynamics. Cape Town: Pearson

Jain, V. (2014). 3D model of attitude. International Journal of Advanced Research in Management and Social Sciences, 3(3), 1-12. 
Johnson, D. W. \& Johnson, R. T. (2002). Meaningful assessment: A manageable and cooperative process. Boston: Allyn \& Bacon.

Karami, A. \& Rezaei, A. (2015). An overview of peer assessment: The benefits and Importance. Journal for the Study of English Linguistics, 3(1), 93-100.

Kaufman, J. H., \& Schunn, C. D. (2011). Students' perceptions about peer assessment for writing: Their origin and impact on revision work. Instructional Science, 39(3), 387-406.

Kayler, M., \& Weller, K. (2007). Pedagogy, self-assessment, and online discussion Groups. Educational Technology \& Society, 10(1), 136-147.

Khonbi, Z. A., \& Sadeghi, K. (2012). The effect of assessment type (self vs. peer vs. teacher) on Iranian University EFL students' course achievement. Language Testing in Asia, 2(4), 47-74

Killen, R. (2007). Teaching strategies for outcomes-based education. South Africa, ZA: Juta.

Kollar, I., \& Fischer, F., (2010). Peer assessment as collaborative learning: A cognitive perspective. Learning and Instruction 20(4), 344-348.

Li, Y., \& Chen, L. (2016). Peer- and self-assessment: a case study to improve the students' learning ability. Journal of Language Teaching and Research. 7(4), 780-787.

Liu, N-F \& Carless, D. 2006. Peer feedback: the learning element of peer assessment. Teaching in Higher Education, 11(3), 279-290.

McMillan, J. H. \& Hearn, J. (2008). Student self-assessment: The key to stronger student motivation and higher achievement. Educational Horizons, 87(1), 40-49.

Marhaeni, A. A. I. N. \& Artini, L. P. (2015). Asesmen autentik dan pendidikan bermakna: Implementasi Kurikulum 2013 [Authentic assessment and meaningful education: Implementation of curriculum 2013]. Jurnal Pendidikan Indonesia, 4(1), 499-511.

Mok, M. M. C., Lung, C. L., Cheng, D. P. W., Cheung, R. H. P., \& Ng, M. L. (2006). Assessment \& evaluation in higher education self-assessment in higher education: experience in using a metacognitive approach in five case studies. Assessment \& Evaluation in Higher Education, 31(4), 415-433.

Mueller, J. (2006). The authentic assessment toolbox. Retrieved 19 March, 2017 from http://jonathan.mueller.faculty.noctrl.edu/toolbox/standardtypes.htm

Munoz, A. \& Alvarez, M.E. (2007). Students' objectivity and perception of self assessment in an EFL classroom. The Journal of ASIA TEFL, 4(2), 1-25.

Nortcliffe, A. (2012). Can students assess themselves and their peers? - A Five Year Study. Student Engagement and Experience Journal, 1(2), 1-16.

Orawiwatnakul, W., \& Wichadee, S. (2017). An investigation of undergraduate students' beliefs about autonomous language learning, International Journal of Instruction, 10(1), 117-132.

Orlova, N. (2009). Video recording as a stimulus for reflection in pre-service EFL teacher training. English Teaching Forum, 2, 30-35.

Panadero, E., Tapia, J. A., \& Huertas, J. A. (2012). Rubrics and self- assessment scripts effects on self-regulation, learning and self-efficacy in secondary education. Learning and Individual Differences, 22(1), 806-813. 
Rolheiser, C. \& Ross, J. A. (2005). Student self-evaluation: What research says and what practice shows. Retrieved 28 February, 2016 from Moodle: http://moodle.manistee. org/pluginfile.php/59439/course/section/16807/ student\%20selfevaluation $\% 20$ what $\% 20$ research $\% 20$ says $\% 20$ and $\% 20$ what $\% 20$ practice $\% 20$ shows.pdf.

Ross, J. A. (2006). The reliability, validity, and utility of self-assessment. Practical Assessment Research \& Evaluation, 11(10), 1-13.

Schuck, S., Gordon, S., \& Buchanan, J. (2008). What are we missing here? Problematising wisdoms on teaching quality and professionalism in higher education. Teaching in Higher Education, 13(5), 537-547.

Sellars, M. (2012). Teachers and change: The role of reflective practice. Procedia - Social and Behavioral Sciences, 55, $461-469$.

Sezer, R. (2008). Integration of critical thinking skills into elementary school teacher education courses in Mathematics. Education, 128(3), 349-362.

Sharma, R., Jain, A. Gupta, N., Garg, S., Batta, M., \& Dhir, S. K. (2016). Impact of selfassessment by students on their learning. International Journal of Applied and Basic Medical Research, 6(3), 226-229.

Shepard, L. A. (2000). The role of assessment in a learning culture. Educational Researcher, 29(7), 4-14

Siow, L. F. (2015). Students' perceptions on self- and peer-assessment in enhancing learning experience. The Malaysian Online Journal of Education Science, 3(2), 21-35.

Spiller, D. (2012). Assessment matters: Self-assessment and peer assessment, Retrieved 19 March, 2017 from https://kennslumidstod.hi.is/wp-content/uploads/2016/03/assessmentmatters-self-assessment-and-peer-assessment.pdf

Sun, D. L., Harris, N., Walther, G., \& Baiocchi, M. (2015). Peer assessment enhances student learning: The results of a matched randomized crossover experiment in a college statistics class. Retrieved 20 March, 2017 from http://journals.plos.org/plosone/ article?id=10.1371/journal.pone. 0143177

Thomas, G., Martin, D., \& Pleasants, K. (2011). Using self- and peer-assessment to enhance students' future-learning in higher education. Journal of University Teaching \& Learning Practice, 8(1), 1-17.

Vickerman, P. (2009). Student perspectives on formative peer assessment: an attempt to deepen learning? Assessment \& Evaluation in Higher Education, 34(2), 221-230.

Wallace, M. J. (1998). Action research for language teachers. Cambridge, UK: Cambridge University Press.

Walvoord, B. E. (2010). Assessment clear and simple: A practical guide for institutions, departments and general education. San Francisco, CA: Jossey-Bass.

Wenden, A. (1991). Learner strategies for learner autonomy. London, EN: Prentice Hall.

White, E. (2009). Student perspective of peer assessment for learning in a public speaking course. Asian EFL Journal - Professional Teaching Articles, 33, 1-36.

Willey, K., \& Gardner, A. (2009). Changing students' perceptions of self and peer Assessment. Proceedings of the Research in Engineering Education Symposium, Palm 
Cove, Queensland, 1-9. Retrieved 29 March, 2017 from https://www.google.co.id/?gws_rd=cr,ssl\&ei=LZjbWKX5DYTivgSX7YUY\#q=Willey,+K.+\%26
+Gardner,+A.+(2009).+Changing+students\%E2\% $80 \% 99+$ perceptions+of+self+and+peer+Assessment.+Proc eedings +of+the+Research+in+Engineering+Education+Symposium, + Palm+Cove,+Queensland \&*

Zhu, H. M. (2014). Reflective thinking on EFL classroom discourse. Journal of Language Teaching and Research, 5(6), 1275-1282.

Zwozdiak-Myers, P. (2011). Reflective practice for professional development. In A. Green (Ed) Becoming a reflective English teacher (pp. 26-42). England: Open University Press.

\section{Turkish Abstract}

\section{Yansıtıcı Öğretme Uygulamalarında Benlik ve Akran Değerlendirmeyi Dahil Etme}

$\mathrm{Bu}$ makalede, öğretmen adaylarının, Yansıtıcı Öğretme Sınıflarında ders planlama ve öğretim performansı üzerine benlik ve akran değerlendirme kullanımıyla ilgili algıları üzerine betimleyici bir araştırmanın bulguları sunulmuştur. Ankete 234 öğrenciden rastgele alınan 100 örnek ve odak grup görüşmesine katılan 15 öğrenci (FGD) değerlendirilmiştir. Anketten elde edilen bulgulara göre, benlik ve akran değerlendirmesi için olumlu bir algı elde edilmiştir. Buna ek olarak, odak grup görüşmesine katılan öğrenciler, kendi değerlendirmelerini yaparak, kendi performanslarını derinlemesine değerlendirip, güçlü ve zayıf yönlerini görmeyi öğrenebilmiştir.

Anahtar Kelimeler: ders planı, alg1, yansıtıcı öğretim, benlik ve akran değerlendirmesi, öğretim performans1

\section{French Abstract}

\section{Incorporation Soi et Pair Évaluation dans Pratiques d'Enseignement Réfléchissantes}

Cet article rapporte les découvertes d'une étude descriptive sur la perception des professeurs stagiaires sur l'utilisation de soi et le pair(l'égal) l'évaluation donner l'évaluation en planification de la leçon et de l'enseignement de la performance(prestation) dans la Classe d'Enseignement Réfléchissante(Réfléchie). A là été pris(emmené) 100 échantillons aléatoirement de 234 étudiants dans une enquête(une vue générale) utilisant le questionnaire et 15 étudiants participant dans la discussion de groupe de discussion (FGD). La découverte du questionnaire montre qu'ils avaient une perception très positive vers l'utilisation de soi et le pair(l'égal) l'évaluation. De plus, du FGD, ils transmis en pratiquant le faire soi l'évaluation, ils pourraient apprendre à voir soi la performance (prestation) profondément, des forces et des faiblesses.

Mots Clés: plan de leçon, perception, enseignement réfléchissant (réfléchi), soi et pair(égal) évaluation, performance(prestation) d'enseignement

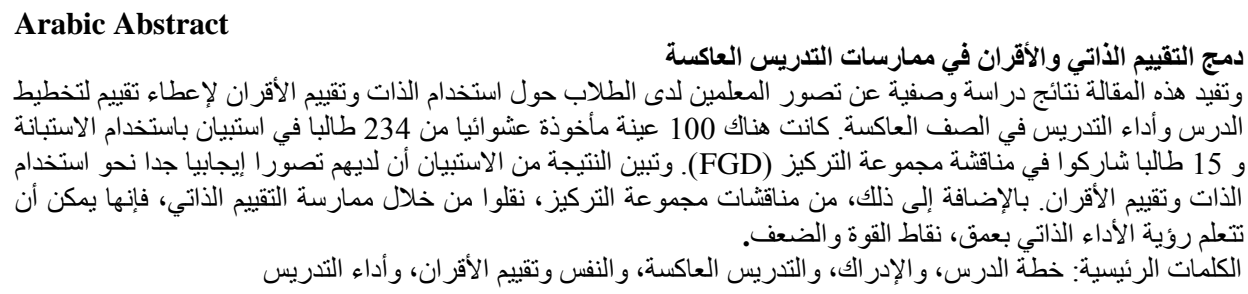

International Journal of Instruction, October $2017 \bullet$ Vol.10, No.4 


\section{German Abstract \\ Einbeziehung von Selbst- und Peer-Assessment in reflektierenden Lehre Praktiken}

Dieser Artikel berichtet über die Ergebnisse einer deskriptiven Studie über die Wahrnehmung der Schülerlehrer über die Verwendung von Selbst- und Peer-Bewertung, um eine Bewertung zur Planung des Unterrichts und der Lehre in der Reflective Teaching Class zu geben. Es wurden 100 Proben zufällig von 234 Studenten in einer Umfrage mit Fragebogen und 15 Studenten, die an der Fokus Gruppendiskussion (FGD) teilgenommen. Der Befund aus dem Fragebogen zeigt, dass sie eine sehr positive Wahrnehmung zum Gebrauch von Selbst- und Peer-Bewertung hatten. Darüber hinaus, von der FGD, vermittelten sie durch Üben selbst Selbsteinschätzung, konnten sie lernen, Selbst-Performance tief zu sehen, Stärken und Schwächen.

Schlüsselwörter: unterrichtsplan, wahrnehmung, reflektierende lehre, selbst- und peer-bewertung, unterrichtsleistung

\section{Malaysian Abstract \\ Menggabungkan Penilaian Kendiri dan Rakan Sebaya dalam Amalan Pengajaran Reflektif}

Artikel ini melaporkan hasil kajian deskriptif mengenai persepsi guru pelajar tentang penggunaan penilaian diri dan rakan sebaya untuk memberi penilaian mengenai perancangan pelajaran dan prestasi mengajar dalam Kelas Pengajaran Reflektif. Terdapat 100 sampel yang diambil secara rawak dari 234 pelajar dalam kaji selidik menggunakan soal selidik dan 15 pelajar yang menyertai dalam perbincangan kumpulan fokus (FGD). Penemuan dari soal selidik menunjukkan bahawa mereka mempunyai persepsi yang sangat positif terhadap penggunaan penilaian kendiri dan rakan sebaya. Di samping itu, dari FGD, mereka menyampaikan dengan melakukan amalan penilaian sendiri, mereka dapat belajar untuk melihat prestasi diri secara mendalam, kekuatan dan kelemahan.

Kata Kunci: pelan pengajaran, persepsi, pengajaran reflektif, penilaian kendiri dan rakan sebaya, prestasi pengajaran

\section{Russian Abstract \\ Включение Самоценки и Экспертной Оценки в Рефлексивную Практику Обучения}

В этой статье сообщается о выводах описательного исследования восприятия учителями учеников об использовании оценки личности и сверстников для оценки результатов планирования урока и обучения в классе рефлексивного обучения. Было проведено 100 выборок случайным образом из 234 студентов в опросе с использованием вопросника и 15 студентов, участвующих в обсуждении фокус-группы. Вывод из вопросника показывает, что у них было очень позитивное восприятие в отношении использования самооценки и экспертной оценки. Кроме того, из обсуждений фокус-групп, которые они передавали, практикуя самооценку, они могли научиться видеть самоэффективность, сильные и слабые стороны более углубленно.

Ключевые Слова: план урока, восприятие, рефлексивное обучение, оценка личности и сверстников, эффективность обучения 